ISSN-Print. 2541-3651

ISSN-Online. 2548 - 3897

Research Article

\title{
UJI EFEK ANTIDIARE INFUSA KULIT BUAH PISANG KEPOK (Musa paradisiaca L. forma typical) TERHADAP MENCIT JANTAN YANG DIINDUKSI OLEUM RICINI
}

\section{ANTIDIARRHEAL EFFECT OF PISANG KEPOK PEEL (Musa paradisiaca $\mathrm{L}$. forma typical) INFUSION IN MALE MICE INDUCED BY OLEUM RICINI}

\author{
Revita Saputri*, Risti Hadiyanti, Eka Fitri Susiani \\ Sekolah Tinggi Ilmu Kesehatan Borneo Lestari Banjarbaru \\ *revita03@gmail.com
}

\begin{abstract}
ABSTRAK
Penggunaan tanaman sebagai pengobatan diare merupakan sumber potensial sebagai alternatif obat tradisional.Kulit Pisang Kepok (Musa paradisiaca L.) merupakan salah satu tanaman yang dapat digunakan sebagai antidiare karena memiliki kandungan senyawa flavonoid, tanin dan saponin.Tujuan dari penelitian ini adalah mengetahui efek anti diare dari infusa Kulit Pisang Kepok pada mencit yang diinduksi dengan oleum ricini dan mengetahui dosis infusa Kulit Pisang Kepok yang memberikan efek antidiare yang paling baik.Kulit Pisang Kepok diekstraksi dengan metode infusa.Pengujian efek antidiare dilakukan dengan menginduksioleum ricinike mencit. Kelompok perlakuan terbagi menjadi 5 kelompok yaitu kelompok 1 (kontrol negative),kelompok 2 (kontrol positif loperamid 2mg), kelompok 3 (infusa Kulit Pisang Kepok 5\% b/v), kelompok 4 (infusa Kulit Pisang Kepok 10\% b/v) dan kelompok 5 (infusa Kulit Pisang Kepok $15 \% \mathrm{~b} / \mathrm{v})$. Pengamatan antidiare dilaksanakan tiap 30 menit selama 4 jam meliputi frekuensi dan konsistensi diare. Hasilpengamatan frekuensi diare menunjukkanterdapat perbedaan bermakna antara kelompok 5 dengan kelompok 1 dilihat dari penurunan frekuensi diare.Hasil penelitian pada konsistensi feses menunjukkankelompok 5memberikan perbaikan konsistensi feses (normal)pada menit ke 180.Infusa Kulit Pisang Kepok 15\% b/vmenunjukkan efek antidiare yang paling baik dibandingkan dengan infusa Kulit Pisang Kepok 5\% b/v dan $10 \% \mathrm{~b} / \mathrm{v}$.
\end{abstract}

Kata Kunci :Antidiare,Kulit Pisang Kepok (Musa paradisiaca L.), infusa 
Borneo Journal of Phamascientech, Vol. 04, No. 01, April Tahun 2020

ISSN-Print. 2541-3651

ISSN-Online. 2548 - 3897

Research Article

\begin{abstract}
The use of plants as a treatment for diarrhea is a potentialsource as an alternative to traditional medicine.Kepok bananapeel(Musa paradisiaca L.)is one of the natural can be used as antidiarrheal because they contain flavonoids, tannins and saponins. The purpose of this study to determine the infusion of kepok banana peel has an antidiarrheal effect on mice induced with oleum ricini and to determine the infusion dose of kepok banana peel which provides the best antidiarrheal effect. Kepok banana peel extracted by infusion method.Testing of the antidiare effect of Kepok banana peel infusion in oleum ricini induces mice. The study was divided into 5 groups : group 1 (control negative), group 2 (control positif loperamid 2mg), group 3 (dose of kepok banana peel infusion 5\% b/v), group 4 (dose of kepok banana peel infusion 10\% b/v), and group 5 (dose of kepok banana peel infusion $15 \% \mathrm{~b} / \mathrm{v}$ ). Antidiarrheal observation in every 30 minutes for 4 hours including the frequency diarrheaand consistency of faecal.The results of frequencydiarrhea showed weresignificantlydifferent betweengroup 5and group 1 which can be seen fromdecreased frequency of diarrhea. The results of consistencyfaecalshowedthat the infusion of kepok banana peel infusion $15 \% \mathrm{~b} / \mathrm{v}$ improved consistency of faecalto be normal at 180 minute observation. Kepok banana peel infusion $15 \% \mathrm{~b} / \mathrm{v}$ showed the best antidiarrheal effect compared tokepok banana peel infusion $5 \% \mathrm{~b} / \mathrm{v}$ and $10 \% \mathrm{~b} / \mathrm{v}$.
\end{abstract}

Keywords: Antidiare, Kepok banana peel (Musa paradisiaca L.), Infusion 
Borneo Journal of Phamascientech, Vol. 04, No. 01, April Tahun 2020

ISSN-Print. 2541-3651

ISSN-Online. 2548 - 3897

Research Article

\section{PENDAHULUAN}

Penyakit diare merupakan masalah kesehatan, hal ini dapat dilihat dengan meningkatnya angka kesakitan akibat diare dari tahun ke tahun. Indonesia merupakan negara dengan angka kesakitan dan angka kematian akibat diare yang masih tinggi, didapat dari Hasil Riset Kesehatan Dasar tahun 2018 menunjukkan $8 \%$ diare terjadi di Indonesia (Kemenkes, 2018). Definisi diare adalah buang air besar dengan konsistensi lembek atau cair, bahkan dapat berupa air saja dengan frekuensi lebih sering dari biasanya (tiga kali atau lebih) dalam satu hari (Depkes RI, 2011).

Masyarakat Indonesia telah lama mengenal dan melakukan pengobatan masalah kesehatan menggunakan tanaman obat.Pengetahuan tentang tanaman obat didapat berdasarkan pengalaman dan keterampilan yang telah diwariskan oleh nenek moyang secara turun-temurun.Salah satu tanaman yang dipercaya dapat memberikan efek sebagai antidiare yaitu Pisang. Berdasarkan
penelitianAhmad, et al. (2016) mengatakan bahwa infusa buah pisangkepok memiliki khasiat sebagai antidiare pada mencit yang diinduksi oleum ricinidengan dosis $5 \% \mathrm{~b} / \mathrm{v}, 10 \% \mathrm{~b} / \mathrm{v}$ dan $15 \% \mathrm{~b} / \mathrm{v}$. Penelitian Sihotang (2014), menunjukkan bahwa ekstrak etanol $70 \%$ kulit buah pisang kepok memiliki aktivitas sebagai antidiare paling efektif yaitu konsentrasi 5\% dengan dosis $30 \mathrm{mg}$. Penelitian yang dilakukan oleh Lumowa dan Bardin (2017), menunjukkan bahwa kulit buah Pisang kepok mengandung senyawa flavonoid, alkaloid, tanin, triterpinoid dan saponin. Senyawa metabolit sekunder golongan tanin, flavonoid, alkaloid, saponin, steroid dan terpenoid diduga memberikan efek antidiare dari beberapa tanaman obat seperti antimodilitas, anti sekretori dan antibakteri (Anas, et al., 2012).Berdasarkan latar belakang diatas, maka dilakukan penelitian untuk mengetahui efek dan dosis yang paling efektif dari infusa kulit pisang kepok. 
Borneo Journal of Phamascientech, Vol. 04, No. 01, April Tahun 2020

ISSN-Print. 2541-3651

ISSN-Online. 2548 - 3897

Research Article

\section{METODOLOGI}

\section{Alat dan bahan}

Alat-alat yang digunakan adalah Spuilt oral 1cc, seperangkat alat ekstraksi infusa,stopwatch. Bahanbahan yang digunakan dalam penelitian ini adalah akuades, Kulit Pisang Kepok (Musa paradisiaca L. forma typica), kertas saring, Loperamid, Minyak jarak (Oleum ricini), hewan uji (mencit) dengan usia 2-3 bulan dan bobot badan 2030 gram.

\section{Pembuatan infusa kulit pisang kepok}

Pembuatan infusa Kulit Pisang Kepok dengan konsentrasi yang telah ditentukan untuk pembuatan dengan konsentrasi 5\% b/v dilakukan dengan cara menimbang 5 gram kulit buah pisang kepok yang masih segar, yang dimasukkan kedalam penangas air lalu ditambahkan air sebanyak $100 \mathrm{ml}$ kemudian direbus dengan nyala api yang kecil sampai suhu $90^{\circ} \mathrm{C}$ dan hitung selama 15 menit sambil sesekali di aduk. Serkai menggunakan kain flanel selagi panas.Pembuatan infusa dengan konsentrasi $10 \% \mathrm{~b} / \mathrm{v}$ dan $15 \% \mathrm{~b} / \mathrm{v}$, masing-masing ditimbang 10 gram dan 15 gram dan dilakukan dengan perlakuan yang sama dengan konsentrasi $5 \%$ b/v. Masing-masing konsentrasi ditambahkan volume ekstra sebanyak $10 \%$.

\section{Skrinning fitokimia}

\section{Uji Flavonoid}

Infusa Kulit Pisang Kepok sebanyak $2 \mathrm{ml}$ dalam tabung reaksi ditambahkan 10 tetes $\mathrm{HCl}$ pekat dan 0,1 gram serbuk logam magnesium. Flavonoid ditandai dengan adanya warna merah jingga hingga merah ungu (DepKes RI, 1995)

\section{Uji Saponin}

Infusa Kulit Pisang Kepok ditambahkan $10 \mathrm{ml}$ air panas didalam tabung reaksi, didinginkan dan dikocok selama 10 detik. Adanya saponin ditandai dengan buih selama 10 menit setinggi $1-10 \mathrm{~cm}$. Penambahan $\mathrm{HCl} 2 \mathrm{~N}$ buih tidak hilang (DepKes RI, 1995).

\section{Uji Tanin}

Infusa Kulit Pisang Kepok $1 \mathrm{ml}$ di dalam tabung reaksi.Ditambahkan beberapa tetes $\mathrm{FeCl}_{3}$, terbentuknya warna biru tua atau hitam kehijauan 
Borneo Journal of Phamascientech, Vol. 04, No. 01, April Tahun 2020

ISSN-Print. 2541-3651

ISSN-Online. 2548 - 3897

Research Article

menunjukkan adanya senyawa tanin (Lumowa \& Bardin. 2017).

\section{Uji Alkaloid}

Infusa Kulit Pisang Kepok $1 \mathrm{ml} \mathrm{di}$ dalam cawan porselin, ditambahkan asam klorida $2 \mathrm{~N}$ dan $9 \mathrm{ml}$ air, lalu dipanaskan diatas penangas air selama 2 menit, dinginkan dan saring. Tiga tetes filtrat di pindahkan pada kaca arloji, pereaksi Mayer 1 tetes ditambahkan jika terbentuk endapan putih atau kuning yang larut dalam metanol menunjukkan adanya alkaloid.Tiga tetes filtrat ditambahkan pereaksi Dragendoff 1 tetes terbentuk endapan jingga. Filtrat ditambahkan 1 tetes pereaksi Wagner dan akanterbentuk endapan warna cokelat menandakan adanya alkaloid (Depkes RI, 1995).

\section{Uji Steroid}

Infusa Kulit Pisang Kepok ambil dan masukkan kedalam tabung reaksi, ditambahkan 2 tetes Kloroform dan 3 tetes pereaksi Lieberman Burchard.Terbentuknya warna merah pada larutan pertama kali dan berubah menjadi warna biru dan hijau. Menunjukkan adanya steroid (Lumowa \& Bardin. 2017)

\section{Pengujian Efek Antidiare}

Pengujian sampel dilakukan dengan 25 ekor hewan uji dengan jenis kelamin jantan dibagi menjadi 5 kelompok secara acak, diaklimatisasi selama 7 hari.Kelomok uji terdiri dari:

a. kelompok 1 : kontrol negatif (akuades)

b. Kelompok 2: kontrol positif (loperamide $2 \mathrm{mg}$ )

c. Kelompok 3: infusa Kulit Pisang Kepok dengan konsentrasi 5\% b/v d. Kelompok 4: infusa Kulit Pisang Kepok dengan konsentrasi10\% $\mathrm{b} / \mathrm{v}$

e. Kelompok 5: infusa Kulit Pisang Kepok dengan konsentrasi 15\% $\mathrm{b} / \mathrm{v}$

Oleum ricini diberikan secara peroral $0,75 \mathrm{ml}$ pada setiap kelompok uji sebagai penginduksi atau perangsang diare. Satu jam setelah induksi dengan oleu ricini, masing-masing hewan uji diberi sediaan uji sesuai kelompok masingmasing.Hewan uji ditempatkan di dalam bejana individual yang beralaskan kertas saring.Parameter di amatiselang waktu 30 menit selama 4 
Borneo Journal of Phamascientech, Vol. 04, No. 01, April Tahun 2020

ISSN-Print. 2541-3651

ISSN-Online. 2548 - 3897

Research Article

jam meliputi frekuensi diare dan konsistensi fesses (Halisa, 2018; Efek Antidiare Infusa Kulit Pisang Kepok

Suliska et al., 2019). Data dianalisis dengan menggunakan Analisis of Variance (ANOVA) dengan derajat kepercayaan $95 \%$.

\section{HASIL DAN PEMBAHASAN}

Skrining fitokimia Infusa Kulit Pisang Kepok

Skrining fitokimia dilakukan untuk mengetahui kandungan golongan senyawa kimia yang terkandung dalam tanaman. Uji fitokimia pada Kulit Pisang Kepok(Musa paradisiaca L. forma typica) meliputi tanin, saponin, flavonoid, alkaloid dan steroid. Hasil dapat dilihat pada Tabel I.

Tabel I. Hasil Skrining fitokimia infusa kulit pisang kepok

\begin{tabular}{lc}
\hline Uji & Hasil \\
\hline Flavonoid & + \\
Saponin & + \\
Tanin & + \\
Alkaloid & - \\
Steroid & - \\
\hline
\end{tabular}

Keterangan:

$+=$ Terdapat senyawa uji

- = tidak terdapat senyawa uji 
Borneo Journal of Phamascientech, Vol. 04, No. 01, April Tahun 2020

ISSN-Print. 2541-3651

ISSN-Online. 2548 - 3897

Research Article

Tabel II. Data rata-rata frekuensi diare masing-masing kelompok uji

\begin{tabular}{lcccccccccc}
\hline Kelompok & \multicolumn{8}{c}{ rata-rata frekuensi diare } & jumlah \\
\cline { 2 - 8 } & 30 & 60 & 90 & 120 & 150 & 180 & 210 & 240 & total diare \\
\hline Kelompok 1 & 3 & 11 & 10 & 16 & 8 & 11 & 2 & 2 & 63 \\
Kelompok 2 & 2 & 4 & 2 & 3 & 1 & 3 & 0 & 0 & $15^{*}$ \\
Kelompok 3 & 4 & 9 & 3 & 4 & 4 & 7 & 4 & 2 & 37 \\
Kelompok 4 & 2 & 5 & 2 & 4 & 9 & 1 & 1 & 0 & 24 \\
Kelompok 5 & 0 & 3 & 4 & 2 & 3 & 4 & 1 & 0 & $17^{*}$ \\
\hline
\end{tabular}

Keterangan :

*berbeda sig. dengan Kelompok $1(\mathrm{P}<0.05)$

Hasil penelitian menunjukkan

bahwa frekuensi diare kelompok 1 dan 2 mengalami penurunan frekuensi diaresetelah menit ke 180.Padakelompok 3 dan 5 mengalami penurunan frekuensi setelah menit ke 180.Sedangkan pada kelompok 4 mengalami penurunan frekuensi diare setelah menit ke 150. Berdasarkan Tabel II. terlihat bahwa kelompok 2 yang merupakan kontrol positif dan kelompok 5 yang merupakan infusa Kulit Pisang Kepok $15 \% \quad b / v$ menunjukkan frekuensi diare paling sedikit dibandingkan kelompok lainnya.Hasil analisis menunjukkan bahwa data frekuensi diare normal (sig. 0,993>0,05) namun tidak homogen (sig. 0,003 sehingga digunakan analisis Kruskall-wallis untuk

mengetahui perbedaan signifikan antar kelompok kontrol dengan perlakuan.

Berdasarkan TabelII.didapatkan hasil bahwa kelompok 1 sebagai kontrol negatif berbeda signifikan dengan kelompok 2 sebagai kontrol positif dan berbeda signifikan dengan kelompok 5 yaitu Infusa Kulit Pisang Kepok 15\%. Hal ini menunjukkan bahwa kelompok kontrol positif dan kelompok infusa Kulit Pisang Kepok 15\% memiliki efektifitas sebagai antidiare

Parameter selanjutnya adalah konsistensi feses. Konsistensi feses dikategorikan menjadi 3 yaitu Normal (N), Lembek (L) dan Cair (C). Konsistensi feses dinilai dengan menggunakan kategori.Pengamatan 
Borneo Journal of Phamascientech, Vol. 04, No. 01, April Tahun 2020

ISSN-Print. 2541-3651

ISSN-Online. 2548 - 3897

Research Article

konsistensi feses dapat dilihat pada

Tabel III.

Tabel III. Hasil pengamatan konsistensi fesses mencit

\begin{tabular}{lllllllll}
\hline Kelompok & \multicolumn{10}{c}{ Waktu } \\
\cline { 2 - 9 } & 30 & 60 & 90 & 120 & 160 & 180 & 210 & 240 \\
\hline Kelompok 1 & N & N & L & C & C & C & C & C \\
Kelompok 2 & N & N & N & N & N & L & - & - \\
Kelompok 3 & N & N & L & L & L & C & C & L \\
Kelompok 4 & N & N & L & C & L & L & C & C \\
Kelompok 5 & - & N & N & L & L & N & N & - \\
\hline
\end{tabular}

Keterangan :

$\mathrm{N}=$ Normal, $\mathrm{L}=$ Lembek, $\mathrm{C}=$ Cair

Berdasarkan Tabel III. menunjukkan bahwa kelompok 1 tidak mengalami perbaikan konsistensi hingga menit ke 240. Hal tersebut dikarenakan kelompok 1 merupakan kontrol negatif dimana tidak terdapat sediaan uji atau obat sebagai antidiare. Sedangkan pada kelompok 2yang diberikan obat loperamid sebagai kontrol positif terlihat memberikan efek sebagai antidiare dimana konsistensi fesses pada menit tetap normal. Loperamide memiliki efek sebagai antidiare dengan cara mengurangi gerakanperistaltik, sehingga dapat menormalkan keseimbangan resorpsi dari sel mukosa, yaitu memulihkan sel-sel yang berada dalam keadaan hipersekresi keadaan hipersekresi ke keadaan normal kembali (Adrianto, et al. 2017).Pada kelompok 3 dan 4tidak menunjukkan perbaikan konsistensi feses.Sedangkan pada kelompok 5 terlihat perbaikan konsistensi sejak menit ke 180.Dari hasil pengamatan tersebut dapatdilihat bahwa kelompok 5 menunjukkan perbaikan konsistensi feses lebih baik daripada kelompok 3 dan 4.

Berdasarkan hasil skrining fitokimia diperoleh bahwa infusa Kulit Pisang Kepok mengandung flavonoid, saponin, dan tanin.Hal ini berkesesuaian dengan penelitian (Sihotang, 2014) dimana kulit buah pisang kepok (Musa paradisiaca L.) mengandung senyawa flavonoid, saponin dan tanin, namun menunjukkan hasil yang berbeda pada senyawa steroid. Beberapa penelitian menyebutkan bahwa senyawa-senyawa tersebut diduga berperan dalam memberikan efek sebagai antidiare Senyawa flavonoid diduga memiliki mekanisme menghentikan diare dengan 
Borneo Journal of Phamascientech, Vol. 04, No. 01, April Tahun 2020

ISSN-Print. 2541-3651

ISSN-Online. 2548 - 3897

Research Article

menghambat motilitas usus sehingga mengurangi sekresi cairan dan elektrolit (Sugipratiwi, et al. 2016).Senyawa tanin adalah salah satu senyawa yang dipercaya dapat memberikan efek antidiare, tanin dapat berfungsi sebagai adstringensia saluran cerna dengan mekanisme menciutkan pori-pori dan selaput lendir usus (Adrianto, et al. 2017). Senyawa saponin juga diduga memberikan efek antidiare dengan cara menghambat pelepasan histamnin secara in vitro (Anas, et al. 2012).

\section{KESIMPULAN}

Kesimpulan yang di peroleh dari penelitian ini yaitu :

1. Infusa Kulit Pisang Kepok (Musa paradisiaca L.) konsentrasi 5\% $\mathrm{b} / \mathrm{v}, \quad 10 \% \quad \mathrm{~b} / \mathrm{v}$ dan $15 \% \quad \mathrm{~b} / \mathrm{v}$ memiliki efek sebagai antidiare.

2. Infusa Kulit Pisang Kepok (Musa paradisiaca L.) yang memberikan efek antidiare paling baik adalah $15 \% \mathrm{~b} / \mathrm{v}$.

\section{DAFTAR PUSTAKA}

Adrianto, A., J. Santoso, E. Suprasetya. 2017. Uji Efektivitas Antidiare Ekstrak Etanol Daun Bidara (Ziziphus maurtiana Lam.) pada mencit jantan (Mus musculus) dengan induksi oleum ricini.Jurnal Permata Indonesia. Vol. 8 (2), 2086-9185

Ahmad, T., A. Aziz, A. Audhi.2016. Uji Efek antidiare rebusan buah pisang kepok(Musa paradisiaca L.)Terhadap mencit. Makassar: Poltekes KemenkesMakassar. Akademi Farmasi Yamasi Makassar.

Anas, Y., Fitria F.R., Purnamasari A.Y., Ningsih A.K., Noviantoro G.A., Suharjono. 2012. Aktivitas Antidiare Ekstrak Etanol Daun Randu (Ceiba petandra L. Gaern.) Pada Mencit Jantan Galur Balb/C. Fakultas Farmasi Universitas Wahid Hasyim Dan Fakultas Kedokteran Universitas Diponegoro. Semarang

Depkes, RI. 1995. Farmakope Indonesia. Edisi IV. Departemen Kesehatan Republik Indonesia. Jakarta.

Depkes, RI. 2011. Buletin Data dan Informasi Kesehatan Situasi Diare di Indonesia.Kementrian Kesehatan Republik Indonesia. Jakarta. 
Borneo Journal of Phamascientech, Vol. 04, No. 01, April Tahun 2020

ISSN-Print. 2541-3651

ISSN-Online. 2548 - 3897

Research Article

Halisah, N. 2018.Uji Efektivitas Antidiare Ekstrak Etil Asetat Daun Sawo(Manilkara zapota L.) Terhadap Mencit Jantan Yang Diinduksi Oleum Ricini. Karya Tulis Ilmiah. Program Studi D-III Farmasi.Sekolah Tinggi Ilmu Kesehatan Borneo Lestari.Banjarbaru.

Kemenkes RI. 2011. Panduan Sosialisasi Tatalaksana Diare pada Balita.Direktorat Jendral Pengendalian Penyakit dan Penyehatan Lingkungan. Jakarta.

Kemenkes RI. 2018. Riset Kesehatan Dasa. RISKESDAS. Balitbang Kemenkes RI. Jakarta.

Lumowa, S. V. T. \& S. Bardin. 2017.

Uji Fitkomia Kulit Pisang Kepok (Musa paradisiaca L.) Bahan Alam Sebagai Pestisida Nabati Berpotensi Menekan Serangan Serangga Hama Tanaman Umur Pendek.Jurnal Sains dan Kesehatan. Vol 1:(9) 2303-0267.

Sihotang, Y. M. 2014. Karakteristik Dan Skrining Fitokimia Serta Uji Efek Antidiare Ekstrak Kulit Pisang Kepok (Musa X paradisiaca $A B B$ ) Pada Tikus Putih Jantan (Rattus norvegicus). Skripsi.Program Ekstensi Sarjana Farmasi. Fakultas Farmasi. Universitas Sumatera Utara. Medan

Suliska, N., T. Dwi E., Herlinda. 2019. Efek Antidiare Infusa Daun Senggani (Melastoma malabathricum L.) pada Mencit Jantan Galur Swiss Webster yang di Induksi Oleum Ricini. Jurnal Ilmu Kefarmasian Indonesia. Vol. 17 (2): 126-131 